\title{
STUDI RENCANA ALAT PENGUKUR PANAS PADA MUAI LOGAM
}

\author{
Ulul Ilmi ${ }^{1}$ \\ Program Studi, Teknik Elektro, Fakultas Teknik,Universitas Islam Lamongan \\ Jln. Veteran No.53 A Lamongan \\ Telp. +6285646029702 \\ ululilmi78@yahoo.co.id
}

\begin{abstract}
Measurement is the process of comparing measuring devices against measured objects. For measurement of magnitude a measurement tool is needed. In this research activity, the object to be measured is the temperature at the metal expansion. To realize this goal, it is necessary to study the temperature measuring device on the metal expansion. The sensor used for temperature measuring devices is LM35 which is equipped by Arduino and LCD. Based on the test results obtained voltage values measured by a multimeter with an LCD display close to 100 percent or about 99.99 percent. With these results it can be concluded that the temperature measurement meter is in accordance with the expected research objectives.
\end{abstract}

Keyword: Temperature Sensor, Arduino, Metal Expansion, LCD

\section{PENDAHULUAN}

Pengukuran itu adalah membandingkan nilai suatu besaran yang diukur dengan menggunakan besaran sejenis yang ditetapkan sebagai satuan. Pengukuran merupakan sebuah kegiatan yang tidak dapat dipisahkan dalam setiap kegiatan ilmiah. Hanya saja objek yang diukur jelas berbeda. Ada objek pengukuran yang bersifat sosial dan ada pula objek pengukuran yang bersifat eksakta. Pengukuran yang bersifat sosial biasanya menyangkut penelitian yang bersifat sosial dan masih berhubungan dengan makhluk hidup. Adapun pengukuran yang bersifat eksakta biasa menyangkut parameter benda mati seperti suhu lingkungan, massa jenis benda ataupun parameter lainnya. Namun demikian, sesungguhnya batas objek pengukuran antara pengukuran sosial dan pengukuran eksakta tidak ada aturan yang jelas. Yang ada hanyalah seringkali terjadi kombinasi antara pengukuran eksakta dan pengukuran sosial. Pengukuran, pemantauan dan tampilan nilai suhu adalah bagian sistem yang seringkali dibutuhkan dilingkungan, dalam suatu sistem elektronika, maupun dalam industri. Namun studi tentang alat ini dilatarbelakangi karena sensor temperatur merupakan salah satu sistem yang penting untuk memantau dan memberikan informasi mengenai temperatur di suatu tempat. Temperatur merupakan informasi yang sangat penting dalam menentukan kondisi cuaca pada suatu daerah. Banyak hal bergantung pada kondisi temperatur. Makhluk hidup pun sangat bergantung pada kondisi temperatur daerah yang di tempatinya. Aplikasi ini berfungsi untuk mendeteksi temperatur pada suatu tempat. Sensor temperatur lingkungan dengan output digital adalah sebuah alat yang mampu mengukur suhu dengan tingkat keakurasian yang cukup baik, mudah digunakan, dan dapat dengan luas diterapkan. Keluarannya yang berupa data digital memudahkan dalam penghitungan temperatur sekitar, dibanding pengukuran data secara analog. Dari sistem pengukuran ini masih banyak dilakukan secara manual sehingga kendala yang terjadi adalah ketidak akuratan hasil pengukuran tersebut maka penulis mencoba melakukan penelitian dengan melakukan studi tentang rencana pembuatan alat ukur suhu sehingga dapat meminimalisasi terjadinya ketidakakuratan dalam pengukuran.

Dalam penelitian ini, rumusan masalah yang akan dibahas adalah bagaimana studi rencana alat pengukur panas pada muai logam.

Adapun tujuan penelitian yang akan dicapai adalah untuk mengetahui tentang studi rencana alat pengukur panas pada muai logam.

\section{METODE}

Terkait dengan metodologi penelitian, metoologi penelitian yang akan digunakan adalah

1. Penelusuran bahan kepustakaan

Merupakan langkah awal dalam melakukan penelitian ini. Yaitu penulis mengadakan studi literatur terhadap topik yang sedang diteliti dengan mengambil sumber dari buku-buku atau dari internet, serta mengumpulkan bahan-bahan yang ada hubungannya dengan masalah yang sedang diteliti. Metode ini sangat penting karena selain sebagai penuntun dalam teknik penulisan, juga berfungsi sebagai sumber kebenaran terhadap kaidah-kaidah bahasa yang digunakan agar pembaca benar-benar mengerti.

Kata logam berasal dari bahasa Yunani: Metallon yaitu sebuah unsur kimia yang siap membentuk ion (kation) dan mempunyai sebuah ikatan logam, dan bisa dikatakan bahwa ia mirip dengan sebuah kation di awan elektron. Metal ialah salah satu dari tiga kelompok unsur yang dibedakan oleh suatu sifat ionisasi dan ikatan, bersama dengan sebuah metaloid dan nonlogam. Dalam tabel periodik, garis diagonal yang digambar dari boron (B) ke polonium (Po) 
yang membedakan logam dari nonlogam. Unsur dalam garis ini ialah metaloid, bisa juga disebut dengan semi-logam; unsur di kiri bawah ialah logam; unsur ke kanan atas ialah nonlogam.

Nonlogam lebih banyak terdapat di alam daripada logam, tetapi logam banyak terdapat dalam tabel periodik. Beberapa logam terkenal adalah aluminium, tembaga, emas, besi, timah, perak, titanium, uranium, dan zink. Alotrop logam cenderung mengkilap, lembek, dan konduktor yang baik, sementara nonlogam biasanya rapuh (untuk nonlogam padat), tidak mengkilap, dan insulator.Dalam bidang astronomi, istilah logam seringkali dipakai untuk menyebut semua unsur yang lebih berat daripada helium. Adapun jenis-jenis logam

\section{1) Alumunium}

Alumunium ialah sebuah logam dengan warna putih yang keperak-perakan yang mempunyai sifat sangat ringan dan tahan terhadap korosi(karat). Logam yang satu ini berasal dari bijihnya, bauksit, dengan suatu proses elektrolisis. Alumunium ini digunakan dalam kabel-kabel listrik lintas udara, pesawat terbang, kapal, mobil, kaleg minuman, foil dapur (pembungkus makanan), dan lain sebagainya.

2) Baja

Baja ialah salah satu aloi yang sangat sering didengar dan dijumpai namanya. Baja merupakan aloi besi dan karbon yang merupakan satu dari sedikit bahan yang terpenting dalam industri, seperti yang kita ketahui, biasanya industri ini mempengaruhi dunia secara global. Baja mempunyai sifat tahan karat, dan kegunaanya yang sangat penting ialah untuk bidang industri di ruang angkasa.

3) Besi

Besi ialah salah satu jenis logam yang mempunyai warna abu-abu keputih-putihan. Logam ini dihasilkan terutama dari peleburan biji hematit dalam tanur sembur. Kegunaanya ialah diapakai untuk bangunan dan bidang teknik, juga bisa dimanfaatkan untuk membuat suatu aloi baja.

4) Emas

Unsur logam emas mempunyai sifat yang lunak, dan mempunyai warna kuning terang yang digunakan untuk sebuah perhiasan dan alat-alat elektronik. Tentunya emas tidak mudah didapat di pasaran, karena mempunyai harga yang sangat tinggi dan terus meningkat.

5) Kalium

Kalium ialah salah satu jenis logam yang mempunyai berat yang ringan dengan warna keperakan, juga mempunyai suatu sifat sangat reaktif. Senyawa-senyawa kalium ini digunakan dalam sebuah pupuk kimia dan untuk dalam pembuatan kaca.

6) Kuningan

Kuningan ialah salah satu jenis logam yang mempunyai sebuah aloi yang terbuat dari tembaga dan seng. Dalam pemanfaatanya sangat banyak terjadi di bumi ini, yaitu untuk barangbarang hiasan, sekrup, alat-alat musik, pakupaku kecil, dan lain sebagainya.

7) Kupronikel

Kupronikel ialah sebuah aloi yang terbuat dari sebuah tembaga dan nikel yang digunakan untuk membuat uang logam yang berwarna perak.

8) Kromium

Kromium ialah salah satu jenis logam yang mempunyai warna abu-abu, dan memiliki sifat yang keras. jenis satu ini Sering digunakan untuk membuat sebuah baja tahan karat dan melapisi sebuah logam-logam lain untuk melindunginya dan memberi penampikan mengkilap yang memantul.

9) Magnesium

Magnesium ialah salah satu jenis logam yang mempunyai berat yang ringan dan mempunyai warna perak keputih-putihan yang bila terbakar akan menghasilkan nyala api putih terang, logam ini digunakan dalam suara penyelamatan dan kembang api dalam aloi-aloi ringan.

10) Natrium

Natrium ialah salah satu jenis logam yang sangat reaktif, yang mempunyai sifat lunak dan berwarna putih keperakan logam ini terdapat dalam sebuah garam dapur dan digunakan untuk lampu jalanan dan dalam industri kimia.

11) Perak

Perak ialah salah satu jenis logam yang mudah dibentuk, dan mempunyai warna putih abu-abu yang merupakan konduktor panas dan listrik yang sangat baik. Logam ini digunakan untuk membuat sebuah perhiasan, peralatan perak ,dan film fotografi.

\section{Diskusi}

Pada tahap ini penulis melakukan tanya jawab dengan sesama dosen dan rekan kerja mengenai rencana studi dari rancangan perangkat keras. Diharapkan dengan adanya tanya jawab ini akan diperoleh suatu petunjuk tentang bagaimana cara mewujudkan sebuah alat ukur suhu yang tepat. 


\section{Metode analisis}

Dalam metode ini dilakukan analisa semua data yang diperoleh dari berbagai kondisi yang terdapat pada sistem pengukuran baik perangkat keras maupun perangkat lunak. Dari analisa yang dilakukan dapat diambil kesimpulan untuk pengembangan lebih lanjut.

Pemuaian logam termasuk kategori pemuaian zat padat. Pemuaian zat padat dapat ditinjau dari pemuaian panjang, pemuaian luas, dan pemuaian volume. Pemuaian zat padat terjadi karena bedan padat tersebut mengalami perubahan suhu dari suhu rendah ke tinggi. Besarnya pemuaian zat padat tergantung dari koefisien muai dari benda padat tersebut. Hampir semua zat padat akan memuai jika dipanaskan. Setiap benda padat yang dipanaskan akan mengalami pemuaian panjang, pemuaian luas dan pemuaian volume. Pemuaian itu dapat berupa bertambah panjang (linear), bertambah luas, atau bertambah volumenya. Hal ini karena partikelpartikel benda akan bergerak lebih cepat jika suhunya dinaikkan. Karena gerakan inilah partikel membutuhkan ruang yang lebih luas untuk bergerak. Akibatnya, volume zat padat tersebut bertambah besar. Pemuaian logam merupakan manifestasi dari muai panjang. Muai panjang berbagai macam benda padat dapat diselidiki dengan alat Musschenbroek. Jika batang logam yang dipasang pada alat Musschenbroek dipanaskan maka batang logam akan bertambah panjang. Namun, pertambahan panjang batang logam yang satu dengan yang lain berbeda. Artinya, tingkat pemuaian logam-logam tersebut juga berbeda. Logam yang paling besar pemuaiannya akan mendorong jarum penunjuk hingga berputar paling jauh, sedangkan logam yang pemuaiannya paling kecil akan mendorong jarum penunjuk berputar paling dekat. Jika digunakan batang logam aluminium, baja, dan besi maka logam aluminium memuai paling besar, sedangkan besi adalah logam yang memuai paling kecil. Alat Musschenbroek dapat menunjukkan

a. pemuaian dan pertambahan panjang zat padat jika dipanaskan;

b. pemuaian zat padat tergantung pada jenis zat padat itu;

c. pemuaian zat padat sebanding dengan kenaikan suhunya.

Pemuaian dalam zat padat sebenarnya terjadi ke semua arah, yaitu memanjang, melebar, dan menebal. Namun, pengukuran pemuaian panjang pada benda padat sudah dianggap cukup memadai untuk mewakili pemuaian luas. Misalnya, menghitung pemuaian luas sebuah benda yang berupa lembaran tipis berbentuk persegi panjang dengan menghitung terlebih dahulu muai panjang dan muai lebarnya dengan persamaan yang berlaku pada pemuaian panjang.
4. Diagram Blok Penelitian

Terkait diagram blok penelitian, dapat dituliskan berikut ini.

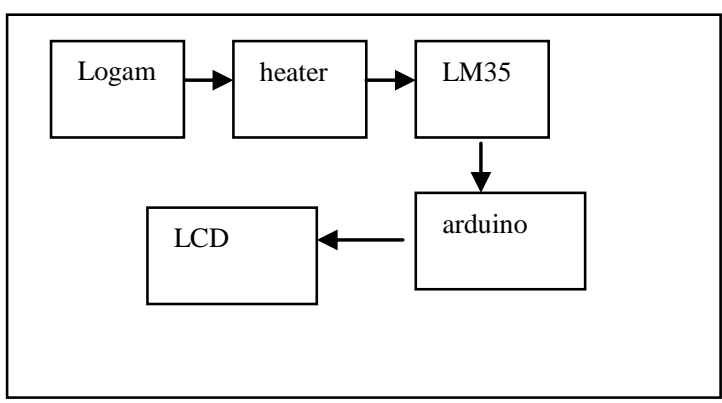

Gambar 1. diagram blok penelitian

\section{PEMBAHASAN}

Pada sensor LM35 penulis mendapatkan data tersebut berupa suhu yang terbaca dari suhu logam, dimana suhu tersebut berupa suhu logam yang dapat dilihat pada LCD. Pengujian sensor IC LM35 ini bertujuan untuk menguji resolusi pada IC LM35 dan pengkalibrasian temperatur terhadap temperatur literatur. Pada datasheet IC LM35 tersebut memiliki resolusi sebesar $10 \mathrm{mV} /{ }^{\circ} \mathrm{C}$, artinya tegangan akan naik $10 \mathrm{mV}$ setiap kenaikan $1^{\circ} \mathrm{C}$. Secara umum rumus respon sensor IC LM35 adalah

$10 \mathrm{mV} \times$ kenaikan suhu $\left({ }^{\circ} \mathrm{C}\right)=$ tegangan yang terbaca $(\mathrm{mV})$. (1).

Dari rumus respon LM35 diatas dapat diketahui pula cara mendapatkan suhu yang direspon oleh sensor IC LM35. Secara umum rumus pembacaan temperatur pada sensor IC LM35 adalah :

tegangan yang terbaca $/ 10 \mathrm{mV}=$ suhu yang diukur $\left({ }^{\circ} \mathrm{C}\right)$

Data perbandingan antara suhu LM35 yang tertampil di LCD dengan tegangan yang terbaca pada multimeter serta data perbandingan antara suhu yang terbaca pada termometer dengan suhu yang terbaca pada LM35 dapat di lihat d termometer dengan suhu yang terbaca pada LM35 dapat di lihat pada bagian selanjutnya.

Tabel 1. Kalibrasi tegangan listrik antara alat ukur mulitimeter dan tampilan LCD

\begin{tabular}{lll}
\hline No & $\begin{array}{l}\text { Tegangan multimeter } \\
(\mathrm{V})\end{array}$ & $\begin{array}{l}\text { Tegangan } \\
\text { tampilan LCD }\end{array}$ \\
\hline 1 & 1 & 0,99 \\
2 & 2 & 1,98 \\
3 & 3 & 2,99 \\
4 & 4 & 3,97 \\
5 & 5 & 4,98 \\
\hline
\end{tabular}

Berdasarkan hasil ini dapat dituliskan bahwa studi tentang alat ukur pada muai logam telah 
menunjukkan hasil yang sesuai dengan rencana semula.

\section{KESIMPULAN}

Berdasarkan uraian sebelumnya dapat disimpulkan sensor LM35 sebagai sensor suhu yang sangat handal untuk kepentingan studi tentang alat ukur suhu pada muai logam. Dengan hasil ini dapat dismpulkan studi tentang alat ukur suhu pada muai logam telah bersesuaian dengan hasil yang diharapkan.

\section{PUSTAKA}

Budiarto, Widodo.2015.Perancangan Sistem dan Aplikasi Mikrokontroller. Jakarta: PT. Elex Media Computindo

Budiarto, Widodo,2017. Belajar Sendiri Membuat Robot Cerdas. Jakarta : PT. Elex Media Komputindo

Dinata, Yuwono Marta, 2016. Arduino itu Mudah. Jakarta. Kompas Gramedia 